\title{
Persepsi dan Partisipasi Petani dalam Pelaksanaan Rehabilitasi Tanaman Kakao di Kabupaten Sigi Provinsi Sulawesi Tengah
}

\section{Perception and Participation Farmers in Rehabilitation Cacao Plants in Sigi District Province of Central Sulawesi}

\author{
Azwar $^{1}$, Pudji Muljono ${ }^{2}$, Tin Herawati ${ }^{2}$ \\ ${ }^{1}$ Alumni Universitas Tadulako Palu, Sulawesi Tengah \\ ${ }^{2}$ Departemen Sains Komunikasi dan Pengembangan Masyarakat, Fakultas Ekologi Manusia, \\ Institut Pertanian Bogor, Bogor
}

\begin{abstract}
Perception of farmers to a program is a cornerstone of major or basic for the emergence of signs of willingness to get involved or participate in a program. This study aims to analyze: 1) perception farmers in program the national movement of cocoa, 2) the participation level of farmers in the program implementation the national movement of cocoa, 3) the correlation between internal factors and external factors to perception in the program national movement of cocoa, and 4) the correlation between internal factors and external factors to participations in the program national movement of cocoa. The data collected in Februari to Maret 2015 in Sigi District. The sample were 100 farmers who were involved in the program gernas cocoa. The analysis of data was performed by using the correlation test of Rank Spearman. The result showed perception and participation level of farmers in national movement of cocoa program was of average level. The internal characteristics correlated positively with farmers' perception to benefit the program only variable cosmopolitan, internal characteristics correlated positively with farmers' perception to implementation of program consists of broad plots and cosmopolitan. The external factors correlated with farmers perception to benefit the program were support market, the availability of labor, availability of information and intensity counseling. External factors correlated with perception farmers in implementation program only support the farmers and intensity counseling. The internal characteristics correlated positively with participation were farm experience, broad plots and cosmopolitan. External factors did not correlate with participation.
\end{abstract}

Keywords: Cocoa, farmers, participation, perception

\begin{abstract}
Abstrak
Persepsi petani terhadap suatu program merupakan landasan atau dasar utama bagi timbulnya kesediaan untuk ikut terlibat atau berpartisipasi dalam suatu program. Penelitian bertujuan: 1) Menganalisis persepsi petani, 2) Menganalisis tingkat partisipasi petani dalam pelaksanaan rehabilitasi kakao, 3) Menganalisis hubungan karakteristik internal dan eksternal dengan persepsi, serta 4) Menganalisis hubungan karakteristik internal dan eksternal dengan partisipasi petani. Penelitian dilaksanakan pada Februari-Maret 2015 di Kecamatan Palolo Kabupaten Sigi. Jumlah sampel 100 orang dan merupakan petani yang terlibat dalam program gernas kakao. Data yang digunakan dalam penelitian ini terdiri dari data primer dan data sekunder. Data yang diperoleh dianalisis secara statistik deskriptif dan statistik inferensial (Rank Spearman). Hasil penelitian menunjukkan persepsi dan tingkat partisipasi petani terhadap program gernas kakao cukup baik. Karakteristik internal yang berhubungan dengan persepsi petani adalah variabel kosmopolitan dan luas lahan garapan. Faktor eksternal yang berhubungan dengan persepsi adalah dukungan pasar, ketersediaan tenaga kerja, ketersediaan informasi, kelompok tani serta intensitas penyuluhan. Karakteristik internal yang berhubungan dengan partisipasi adalah pengalaman usaha tani, luas lahan garapan dan kosmopolitan. Faktor eksternal tidak berhubungan dengan partisipasi.
\end{abstract}

Kata kunci: Kakao, petani, partisipasi, persepsi

\section{Pendahuluan}

Perkebunan merupakan salah satu sektor penting dalam pembangunan ekonomi nasional. Sektor ini juga memegang peranan penting dalam meningkatkan penerimaan devisa. Pembangunan sektor perkebunan tidak terlepas dari berbagai dinamika lingkungan nasional maupun global. Sektor perkebunan juga dipengaruhi oleh dinamika pemerintahan pusat

\footnotetext{
${ }^{1}$ Korespondensi penulis

E-mail: azwarrevolusi@gmail.com
}

hingga daerah karena dianggap sebagai salah satu pilihan pemerintah dalam mengentaskan kemiskinan (Sinartani, 2014).

Program-program perkebunan yang digulirkan pemerintah salah satunya adalah Program Gerakan Nasional Kakao (GERNAS), yang tertuang pada Keputusan Menteri Pertanian Nomor: 1643/Kpst/OT. 160/12/2008 tanggal 2 Desember 2008. Gerakan ini bertujuan untuk percepatan peningkatan produktivitas 
dan mutu hasil kakao nasional melalui pemberdayaan secara optimal seluruh pemangku kepentingan serta sumber daya yang tersedia. Gerakan ini dilaksanakan mulai tahun 2009 pada 9 provinsi 40 kabupaten (Kementan, 2012).

Kabupaten Sigi merupakan salah satu kabupaten yang melaksanakan program gerakan nasional kakao di Provinsi Sulawesi Tengah, karena sebagian besar komoditas di sektor perkebunan kabupaten ini merupakan tanaman kakao. Pada umumnya kondisi tanaman di daerah tersebut sudah tua/rusak, kurang terawat dan mudah terserang hama penyakit, sehingga memerlukan upaya perbaikan secara menyeluruh agar produktivitas dan mutu kakao dapat ditingkatkan. Luas areal gerakan nasional peningkatan produksi dan mutu kakao di Kabupten Sigi pada tahun 2011 mencapai 2500 ha, yang terdiri atas peremajaan 1.100 ha, rehabilitasi 1.100 ha, dan intensifikasi 400 ha. Peningkatan luas areal ini diharapkan dapat berdampak pada peningkatan kesejahteraan masyarakat baik secara langsung maupun tidak langsung.

Program-program di bidang perkebunan yang dicanangkan oleh pemerintah, termasuk gerakan nasional tanaman kakao, tidak bisa berjalan parsial dalam pelaksanaannya. Keterlibatan petani turut mempengaruhi kesuksesaan suatu program. Persepsi petani terhadap suatu program merupakan landasan atau dasar utama bagi timbulnya kesediaan untuk ikut terlibat atau berpartisipasi dalam suatu program tersebut. Kumba (2003) mengatakan kesuksesan sebuah program dapat terlaksana melalui peran partisipasi masyarakat secara langsung. Partisipasi petani dalam pelaksanaan program dipengaruhi oleh bagaimana program tersebut dirancang dan bagaimana persepsi masyarakat terhadap program yang akan diterapkan. Oleh karena itu, menjadi penting penelitian ini untuk melihat persepsi dan partisipasi petani dalam program gerakan nasional kakao agar program tersebut dapat mencapai tujuan yang telah dirumuskan.

Persepsi dan partisipasi pada dasarnya dipengaruhi oleh beberapa faktor. Hasil penelitian Puspasari (2010) mengemukakan faktor internal yang berhubungan signifikan yaitu umur, jumlah tanggungan keluarga, dan kekosmopolitan. Hal tersebut menunjukkan faktor internal sangat mempengaruhi persepsi dan partisipasi petani. Penelitian Susiatik (1998) mengemukakan persepsi dan partisipasi petani dipengaruhi oleh umur, tingkat pendidikan baik formal maupun non formal, pendapatan, dan kosmopolitan. Penelitian ini bertujuan: 1) Menganalisis persepsi petani pada pelaksanaan kegiatan rehabilitasi kakao, 2) Menganalisis tingkat partisipasi petani dalam pelaksanaan kegiatan rehabilitasi kakao, 3) Menganalisis hubungan karakteristik internal dan eksternal dengan persepsi petani dalam pelaksanaan rehabilitasi kakao, dan 4) Menganalisis hubungan karakteristik internal dan eksternal dengan partisipasi petani dalam pelaksanaan kegiatan rehabilitasi kakao.

\section{Metode Penelitian}

Penelitian dirancang dengan mengkombinasikan antara penelitian menerangkan (explanatory research) dengan penelitian deskritif (descriptive research). Rancangan penelitian survai bertujuan menjelaskan pengaruh dan hubungan antar peubah melalui pengujian hipotesis. Penelitian dilaksanakan Kecamatan Palolo Kabupaten Sigi Propinsi Sulawesi Tengah. Pemilihan lokasi penelitian dilakukan secara sengaja (purposive) dengan pertimbangan, antara lain: 1) lokasi tersebut memilki areal perkebunan kakao yang dikelola oleh petani dan kelompok-kelompok tani kakao, 2) kelompokkelompok tani tergabung dalam program gernas kakao, 3) aksesibilitas ke lokasi penelitian yang mudah. Penelitian ini dilaksanakan pada bulan Februari-Maret 2015. Sampel dalam penelitian ini adalah sebanyak 100 petani yang mengikuti kegiatan rehabilitasi tanaman kakao, diambil secara acak dan proporsional pada setiap kelompok tani. Data yang digunakan meliputi data primer dan data sekunder.

Data primer diperoleh dengan melakukan observasi lapangan baik dari pengamatan secara fisik ataupun wawancara dengan menggunakan kuisioner terhadap responden terpilih. Data sekunder diperoleh dari penelitian-penelitian terdahulu dan pustaka yang relevan, Kantor Desa, Kantor Kecamatan, Balai Penyuluhan Pertanian, Dinas Pertanian Tanaman Pangan dan Perkebunan, BPS serta literatur-literatur yang mendukung. Analisis data dilakukan dengan analisis statistik deskriptif untuk menjelaskan persepsi, tingkat partisipasi serta karakteristik internal dan faktor eksternal petani. Penentuan kecenderungan nilai responden untuk masing-masing peubah dikelompokkan menjadi tiga kelas kriteria masing-masing adalah 1) rendah 2) sedang 3) tinggi, menggunakan rumus interval kelas, di mana nilai tertinggi dikurangi nilai terendah dibagi jumlah kelas. Analisis statistik inferensial digunakan untuk mengetahui hubungan variabel $\mathrm{X}$ terhadap $\mathrm{Y} 1$ dan $\mathrm{Y} 2$. Analisis korelasi yang digunakan adalah Spearman Rank. 


\section{Hasil dan Pembahasan}

\section{Karakteristik Internal Petani}

Umur petani di Kecamatan Palolo berkisar antara 25-71 tahun dengan rataan umur petani 43 tahun. Umur petani yang mengikuti program gernas kakao didominasi oleh golongan umur 48-71 tahun. Hal ini menunjukkan bahwa sebagian besar petani kakao masih dalam kondisi fisik yang mendukung kegiatan program gernas kakao. Pada bidang pendidikan, sebagian besar petani tidak tamat SD hingga tamat SD sehingga termasuk kategori rendah. Rendahnya pendidikan di tingkat petani di Kecamatan Palolo berkorelasi dengan minimnya sarana dan prasarana pendidikan. Infrastruktur dan persoalan ekonomi keluarga yang tidak mampu membiayai anggota keluarganya untuk sekolah. Tingkat pendidikan akan mempengaruhi petani dalam berpartisipasi pada suatu program, sejalan dengan penelitian Herawati dan Ismail (2006) bahwa pendidikan memiliki hubungan secara nyata dengan partisipasi kontak tani.

Jumlah tanggungan keluarga yang dimiliki petani di Kecamatan Palolo sebagian besar 3-4 orang. Anggota keluarga petani kakao di kecamatan ini terdiri dari istri, anak, adik, orang tua dan anggota keluarga lainnya, di mana kebutuhan sehari-harinya masih ditanggung oleh kepala rumah tangga petani. Sementara itu pengalaman petani dalam usaha tani sudah mencapai 6-14 tahun, termasuk dalam kategori sedang. Hal ini menunjukkan bahwa petani di Kecamatan Palolo sudah cukup berpengalaman dalam usaha tani kakao. Secara umum pengalaman petani memberikan pengaruh yang positif dan signifikan terhadap perilaku petani dalam menanam tanaman kakao.

Luas lahan perkebunan yang dimiliki sebagian besar petani kakao berkisar antara 0,50-1 hektar atau tergolong sempit. Sempitnya luas perkebunan yang dikelola oleh petani kakao dikarenakan akibat alih fungsi lahan dari perkebunan kakao menjadi perkebunan sawit. Sementara untuk tingkat kosmopolitan sebagian besar petani di Kecamatan Palolo sudah sangat tinggi. Tingginya tingkat kosmopolitan tersebut mengindikasikan bahwa petani sudah memiliki keterbukaan dan keinginan untuk mencari informasi tentang suatu teknologi di luar dari lingkungan sosialnya dengan harapan adanya perubahan pengetahuan, sikap dan keterampilan yang dimiliki.

\section{Faktor Eksternal Responden}

Peran penyuluh yang diamati terdiri dari dukungan pasar, ketersedian tenaga kerja, ketersedian informasi, dukungan kelompok tani, dan intensitas penyuluhan. Dukungan pasar sangat dibutuhkan dalam memasarkan biji kakao sebanyak 50\% petani mengatakan bahwa dukungan pasar berada pada kategori tinggi. Tingginya dukungan pasar memperlihatkan petani kakao di Kecamatan Palolo tidak memiliki kendala dalam memasarkan komoditi kakao, serta mampu memberikan keuntungan bagi petani. Selain dukungan pasar, ketersediaan tenaga kerja dan informasi juga penting dalam usaha tani kakao. Hasil penelitian menunjukkan ketersediaan tenaga kerja pada usaha tani kakao dikategorikan sedang yaitu sekitar $40 \%$ dan ketersediaan informasi bagi sebagian responden atau $46 \%$ menyatakan ketersediaan informasi yaitu kadang-kadang tersedia. Hal ini di sebabkan karena minat petani masih lemah dalam mencari informasi serta penggunaan informasi pertanian belum meluas.

Faktor eksternal lainnya adalah dukungan kelompoktanidanintensitaspenyuluhan.Kelompoktani diharapkan mampu menghadapi resiko usaha, mampu memanfaatkan asas skala usaha ekonomi, memiliki kekuatan mandiri dalam menghadapi pihak-pihak lain dalam dunia usaha sebagai salah satu komponen untuk membangun pertanian maju, efisien dan tangguh. Dukungan kelompok tani berdasarkan hasil penelitian, termasuk dalam kategori sedang sehingga dapat disimpulkan bahwa dukungan kelompok tani dalam mengikuti program geranakan nasional kakao belum maksimal. Kelompok tani yang berjalan aktif akan dapat mempermudah kegiatan penyuluhan. Kegiatan penyuluhan yang dilakukan pada gerakan nasional kakao bertujuan untuk memberikan pengetahuan dan keterampilan mengenai budi daya kakao sebagai tanaman unggulan di Kecamatan Palolo. Hasil analisis menunjukkan bahwa 44\% mengikuti penyuluhan, dan tergolong kategori tinggi. Petani kakao rutin mengikuti kegiatan penyuluhan yang dilaksanakan sebulan sekali. Penerapan dan kesesuain materi yang diberikan cukup mudah dipahami oleh petani. Peran ketua kelompok sangat penting dalam kegiatan penyuluhan.

\section{Persepsi Petani terhadap Kegiatan Rehabilitasi pada Program Gerakan Nasional Tanaman Kakao}

Persepsi responden terhadap kegiatan rehabilitasi pada program gernas kakao yang diukur 
Tabel 1. Jumlah dan Persentase Responden berdasarkan Persepsi terhadap Kegiatan Rehabilitasi pada Program Gernas Kakao

\begin{tabular}{clcc}
\hline Persepsi petani & Kategori & Jumlah (Orang) & Presentase (\%) \\
\hline \multirow{3}{*}{ Manfaat program } & Kurang & 20 & 20,0 \\
& Cukup & 45 & 45,0 \\
\multirow{3}{*}{ Pelaksanaan program } & Baik & 35 & 35,0 \\
& Kurang & 12 & 12,0 \\
& Cukup & 47 & 47,0 \\
& Baik & 41 & 41,0 \\
\hline
\end{tabular}

Keterangan $n=100$

dalam penelitian ini adalah persepsi responden pada manfaat program, dan persepsi pada pelaksanaan kegiatan rehabilitasi pada program gernas kakao. Pengamatan tersebut sangat diperlukan mengingat tanaman kakao merupakan sumber pendapatan utama petani di Kecamatan Palolo (Tabel 1).

Hasil analisis menunjukkan bahwa persepsi responden terhadap manfaat kegiatan rehabilitasi sebanyak 45\% tergolong dalam kategori cukup. Keadaan ini menunjukkan bahwa penilaian petani terhadap kegiatan rehabilitasi pada program gernas kakao mampu menambah pengetahuan dan mengatasi masalah dalam usaha tani kakao, sehingga mampu memberikan manfaat bagi petani kakao di Kecamatan Palolo. Persepsi petani dalam melihat kegiatan program gernas untuk menambah pengetahuan didasari oleh pengalaman yang turun temurun dalam mengelolah tanaman kakao. Hal tersebut didukung oleh pendapat (Berlo, 1960) yang mengemukakan bahwa persepsi seseorang dalam membuat sendiri keputusan tentang apa yang diterima dan ditolaknya. Persepsi petani pada umumnya merasakan banyak manfaat dari program gernas ini. Manfaat yang umum yang dirasakan bertambahnya pengetahuan petani dalam usaha budi daya tanaman kakao, bagi petani yang semula hanya mengetahui cara budi daya dari keluarga mereka, namun program gernas memungkinkan mereka mengetahui lebih banyak tentang konsep pemeliharaan, pemangkasan, pemupukan serta panen yang menghasilkan biji kakao yang berkualitas.

Pelaksanaan kegiatan rehabilitasi pada program gernas kakao merupakan upaya untuk meningkatkan kemampuan petani dalam mengembangkan produktivitas tanaman kakao dan berdampak pada pengembangan usaha tani melalui pengetahuan keterampilan dan perubahan sikap secara bertahap serta berkelanjutan. Persepsi pada tingkat pelaksanaan yang diamati dalam penelitian ada tiga hal 1) akses dan lembaga modal, 2) sarana dan prasarana produksi, 3) informasi tentang pengendalian hama. Hal tersebut sesuai yang dikemukan oleh Roger (2003) bahwa tingkat kemudahan suatu inovasi untuk dilihat hasilnya adalah derajad di mana hasil inovasi itu dapat dilihat atau dirasakan oleh penganut yang berpotensi.

Hasil analisis menunjukkan bahwa persepsi terhadap pelaksanaan kegiatan rehabilitasi pada program gernas kakao dalam menunjang usaha tani tergolong dalam kategori cukup baik. Hal ini dapat dilihat sebanyak $47 \%$ responden dalam kategori cukup baik. Hal ini dapat diartikan bahwa secara keseluruhan bahwa responden memiliki pengatahuan yang jelas tentang akses modal, saran dan prasarana produksi, serta informasi tentang pengendalian hama penyakit pada tanaman kakao.

\section{Tingkat Partisipasi Petani pada Pelaksanaan Rehabilitasi Tanaman Kakao}

Partisipasi petani kakao dalam kegiatan rehabilitasi dapat menjadi dukungan yang kuat dalam meningkatkan pendapatan petani kakao (Tabel 2). Penurunan kualitas biji kakao merupakan indikasi bahwa menurunnya partisipasi petani dalam pengelolahan usaha tani kakao. Rehabilitasi tanamankakaodalam penelitianiniyaitu usahamembangun kembali suatu blok tanaman kakao yang kondisinya telah rusak melalui tindakan-tindakan rejuvinasi dan penyulaman untuk mengembalikan ke arah pertumbuhan yang baik agar produksi dan produktivitas meningkat, sehingga dapat meningkatkan kesejahteraan petani. Rehabilitasi tanaman kakao dilaksanakan dengan cara menyambung dengan klon unggul anjuran (klonalisasi).

Hasil analisis dapat diketahui bahwa partisipasi petani pada rehabilitasi tanaman kakao sebanyak 55\% responden dalam kategori cukup. Responden telah memahami manfaat dari program rehabilitasi, namun pengetahuan mengenai teknik rehabilitasi masih kurang. 
Tabel 2. Jumlah dan Persentase Responden berdasarkan Tingkat Partisipasi dalam Rehabilitasi Lahan

\begin{tabular}{llcc}
\hline \multirow{2}{*}{ Partisipasi Petani } & Kategori & Jumlah (Orang) & Presentase (\%) \\
\hline \multirow{3}{*}{ Rehabilitasi tanaman kakao } & Kurang & 34 & 34,0 \\
& Cukup & 55 & 55,0 \\
Keterangan $\mathrm{n}=100$ & Baik & 11 & 11,0 \\
\hline
\end{tabular}

Keterlibatan petani dalam mengikuti kegiatan rehabilitasi tanaman kakao sangat menentukan keberlanjutan dan keberhasilan program gernas kakao. Jika masyarakat sejak awal dari kegiatan dilibatkan maka masyarakat akan timbul rasa memiliki dan rasa tanggung jawab terhadap kegiatan dan secara moral masyarakat merasa memiliki pembangunan karena berpartisipasi.

\section{Hubungan antara Karakteristik Internal dengan Persepsi}

Karakteristik internal yang berhubungan nyata dengan persepsi petani terhadap manfaat keberadaan program hanya variabel kekosmopolitan, sementara pada persepsi petani terhadap tingkat kemudahan pelaksanaan program terdiri dari variabel luas lahan garapan dan kekosmopolitan (Tabel 3).

Umur tidak berkorelasi dengan persepsi petani terhadap manfaat keberadaan program dan tingkat pelaksanaan program. Hal ini dapat dilihat dari nilai koefisien korelasi yang mendekati nol, menunjukkan hubungan yang lemah dan hampir tidak ada korelasi, begitu juga dengan nilai $\mathrm{p}$ value yang lebih besar dari 0,05 menunjukkan tidak terdapat korelasi yang signifikan. Hal ini berarti semakin bertambahnya umur tidak meningkatkan persepsi petani terhadap manfaat kegiatan rehabilitasi kakao, dan tingkat kemudahan pelaksanaan kegiatan rehabilitasi. Kondisi ini disebabkan bertambahnya umur tidak diiringi dengan penambahan informasi kepada petani tentang program gernas kakao. Hasil penelitian ini sejalan dengan penelitian Kartono (2009) yang menunjukkan bahwa umur petani tidak berpengaruh dengan penerapan inovasi pengelolahan tanaman dan sumberdaya terpadu padi sawah.

Pendidikan tidak berkorelasi dengan persepsi petani pada manfaat kegiatan rehabilitasi kakao, dan tingkat kemudahan pelaksanaan kegiatan rehabilitasi kakao dalam menujang usahatani. Berdasarkan pengamatan di lapangan tidak semua petani baik yang berpendidikan mempunyai persepsi yang baik tentang suatu program. Sejalan dengan penelitian yang dilakukan oleh Ifa (2007) yang menyatakan bahwa sebagian besar petani baik yang berpendidikan maupun tidak semua cenderung memberikan persepsi positif terhadap penggunaan pupuk kompos.

Jumlah tanggungan keluarga tidak berkorelasi dengan persepsi petani pada manfaat kegiatan rehabilitasi kakao, dan tingkat kemudahan pelaksanaan kegiatan rehabilitasi kakao. Hal ini menunjukkan bahwa banyak atau sedikit jumlah tanggungan keluarga tidak menentukan persepsi petani dalam melihat suatu program. Berdasarkan pengamatan di lapangan bagi petani yang memiliki jumlah tanggungan sedikit maupun banyak tetap berpersepsi positif terhadap kegiatan rehabilitasi kakao.

Pengalaman usaha tani tidak berkorelasi dengan persepsi petani pada manfaat kegiatan, dan kemudahan pelaksanaan rehabilitasi kakao. Kondisi ini menunjukkan bahwa bertambahnya pengalaman usaha tani seseorang tidak dapat menentukan persepsinya. Hal tersebut sejalan dengan penelitian Kartono (2009) bahwa lamanya pengalaman berusaha tani responden belum cukup kuat dapat meningkatkan secara nyata tingkat persepsi petani terhadap pengelolaan usaha tani padi secara terpadu.

Luas lahan garapan tidak berkorelasi dengan persepsi petani pada manfaat kegiatan rehabilitasi kakao, namun berkorelasi pada persepsi terhadap tingkat kemudahan pelaksanaan kegiatan rehabilitasi kakao. Artinya bahwa semakin luas lahan garapan maka semakin baik persepsi petani terhadap tingkat kemudahan pelaksanaan rehabilitasi kakao. Berdasarkan wawancara di lapangan petani berpendapat bahwa semakin luasnya lahan garapan akan dapat meningkatkan pendapatan petani sehingga hal tersebut menguatkan petani berpersepsi positif. Penguatan persepsi petani perlu dilakukan dengan penglihatan dan pengamatan terhadap lingkungan 
Tabel 3. Nilai Koefisien Korelasi dan Signifikansi Hubungan Faktor Internal dengan Persepsi Petani terhadap Manfaat Kegiatan Rehabilitasi dan Tingkat Kemudahan Pelaksanaan

\begin{tabular}{|c|c|c|c|c|}
\hline \multirow{3}{*}{ Karakteristik Internal } & \multicolumn{4}{|c|}{ Persepsi } \\
\hline & \multicolumn{2}{|c|}{ Manfaat Keberadaan Program } & \multicolumn{2}{|c|}{ Tingkat Kemudahan Pelaksanaan } \\
\hline & $\mathbf{r}_{\mathrm{s}}$ & $\mathbf{P}$ & $\mathbf{r}_{\mathrm{s}}$ & $\mathbf{P}$ \\
\hline Umur & 0,089 & 0,378 & 0,174 & 0,378 \\
\hline Pendidikan & 0,148 & 0,142 & $-0,038$ & 0,705 \\
\hline $\begin{array}{l}\text { Jumlah tanggungan } \\
\text { keluarga }\end{array}$ & 0,015 & 0,879 & 0,003 & 0,976 \\
\hline Pengalaman berusaha tani & 0,191 & 0,057 & 0,178 & 0,077 \\
\hline Luas lahan garapan & 0,144 & 0,153 & $0,244 *$ & 0,014 \\
\hline Kekosmopolitan & $0,201 *$ & 0,045 & $0314 * *$ & 0,001 \\
\hline
\end{tabular}

melalui indra yang dimiliki.

Kosmopolitan merupakan keterbukaan individu terhadap dunia luar untuk dapat menerima suatu ide baru yang belum pernah diketahui sebagai bentuk pembaharuan. Berdasarkan hasil analisis kekosmopolitan berkorelasi secara nyata dengan persepsi petani pada manfaat kegiatan rehabilitasi, dan berkorelasi sangat nyata dengan persepsi pada tingkat kemudahan pelaksanaan kegiatan rehabilitasi kakao. Hal ini dapat dilihat dari nilai koefisien korelasi yang mendekati satu, menunjukkan adanya hubungan yang kuat, begitu juga dengan nilai $p$ value yang lebih kecil dari 0,05 menunjukkan adanya korelasi yang signifikan. Hubungan ini mengambarkan bahwa semakin tinggi tingkat kekosmopolitan suatu individu maka semakin baik persepsinya terhadap suatu program.

Responden yang memiliki tingkat kekosmopolitan tinggi lebih banyak memperoleh informasi dari hal-hal yang dilihat di lingkungannya atau dari berbagai sumber informasi akibat adanya interaksi dengan orang-orang luar yang membawah inovasi baru.

\section{Hubungan antara Faktor Eksternal dengan Persepsi}

Faktor eksternal merupakan keadaan yang mempengaruhi seseorang yang berasal dari luar diri individu tersebut. Faktor eksternal yang dianalisis hubungannya dengan persepsi dalam penelitian ini adalah: dukungan pasar, ketersediaan tenaga kerja, ketersediaan informasi, dukungan kelompok tani dan intensitas penyuluhan. Hasil analisis terdapat pada Tabel 4.
Tabel 4 menunjukkan bahwa variabel dukungan pasar, ketersediaan informasi, dukungan kelompok tani dan intensitas penyuluhan berhubungan sangat nyata dengan persepsi petani terhadap manfaat keberadaan kegiatan rehabilitasi kakao. Sementara faktor eksternal yang berhubungan dengan persepsi petani terhadap tingkat kemudahan pelaksanaan hanya pada dukungan kelompok tani dan intensitas penyuluhan.

Dukungan pasar berkorelasi sangat nyata dengan persepsi petani pada manfaat program gernas kakao, Hal ini dapat dilihat dari nilai koefisien korelasi yang mendekati satu, menunjukkan adanya hubungan yang kuat, begitu juga dengan nilai $\mathrm{p}$ value yang lebih kecil dari 0,05 menunjukkan adanya korelasi yang signifikan. Hubungan ini dapat diartikan bahwa semakin tinggi dukungan pasar maka persepsi petani terhadap manfaat keberadaan kegiatan rehabilitasi kakao semakin baik. Dukungan pasar sangat penting dalam setiap melakukan kegiatan usaha untuk menjamin pemasaran hasil produknya. Begitu juga dengan petani kakao di Kabupaten Sigi, peluang pasar yang besar akan mendorong petani untuk lebih meningkatkan produktivitas dari usahatani kakaonya. Dukungan pasar tidak berhubungan dengan persepsi petani terhadap tingkat kemudahan pelaksanaan, ini mengartikan bahwa semakin besar dukungan pasar tidak dapat membuat persepsi petani semakin baik terhadap tingkat pelaksanaan.

Ketersediaan tenaga kerja tidak berhubungan nyata dengan persepsi petani pada manfaat maupun tingkat kemudahan pelaksanaan kegiatan rehabilitasi kakao. Hal ini dapat diartikan bahwa ketersediaan tenaga kerja bukan merupakan faktor yang menentukan baik tidaknya persepsi petani. Berdasarkan hasil 
Tabel 4. Nilai Koefisien Korelasi dan Signifikansi Hubungan Faktor Eksternal dengan Persepsi Petani

\begin{tabular}{lcccc}
\hline \multirow{2}{*}{ Faktor Exsternal } & \multicolumn{4}{c}{ Persepsi } \\
\cline { 2 - 5 } & \multicolumn{1}{c}{ Manfaat Keberadaan Program } & \multicolumn{2}{c}{ Tingkat Kemudahan Pelaksanaan } \\
\cline { 2 - 5 } & \multicolumn{1}{c}{$\mathbf{r}_{\mathbf{s}}$} & $\mathbf{p}$ & $\mathbf{r}_{\mathrm{s}}$ & $\mathbf{P}$ \\
\hline Dukungan pasar & $0,339^{* *}$ & 0,001 & 0,175 & 0,082 \\
Ketersediaan tenaga kerja & 0,013 & 0,898 & $-0,076$ & 0,450 \\
Ketersediaan informasi & $0,334^{* *}$ & 0,001 & 0,107 & 0,289 \\
Dukungan kelompok tani & $0,319^{* *}$ & 0,001 & $0,265^{* *}$ & 0,008 \\
Intensitas penyuluhan & $0,480^{* *}$ & 0,000 & $0,305^{* *}$ & 0,002 \\
\hline
\end{tabular}

Keterangan: *) Berhubungan nyata pada $\alpha=0,05 * *)$ Berhubungan nyata pada $\alpha=0,01$

wawancara dilapangan petani berpendapat bahwa meskipun ketersediaan tenaga kerja tidak banyak, petani tetap dapat melakukan kegiatan usahatani kakao. Hal ini didukung sebesar 34\% petani masih berumur muda dan tergolong produktif.

Ketersediaan informasi berhubungan sangat nyata dengan persepsi petani terhadap manfaat keberadaan program, namun persepsi pada tingkat kemudahan pelaksanaan program tidak berhubungan nyata. Hubungan ini menunjukkan bahwa semakin banyak informasi yang dapat diterima petani maka persepsi terhadap manfaat kegiatan rehabilitasi semakin baik. Ketersediaan informasi bermanfaat sebagai penguat untuk mempersepsikan secara positif terhadap sesuatu. Di lokasi penelitian informasi mengenai program gernas kakao sangat mudah didapatkan. Informasi tersebut tersedia di ketua kelompok tani, di Balai Penyuluhan, maupun di Dinas Pertanian.

Dukungan kelompok tani berkorelasi sangat nyata dengan persepsi terhadap manfaat maupun pada tingkat kemudahan pelaksanaan kegiatan rehabilitasi dalam program gernas. Besarnya dukungan kelompok tani dapat membuat persepsi petani semakin baik. Hal dikarenakan kelompok dapat berfungsi sebagai sarana kelas belajar, wahana kerjasama serta sebagai unit produksi yang dapat menambah pengetahuan baru bagi petani. Kondisi tersebut menujukan bahwa dukungan kelompok sangat penting dan banyak manfaatnya sejalan dengan penelitian Rukka et al. (2008) bahwa keberadaan kelompok merupakan salah satu potensi yang mempunyai peranan penting dalam membentuk perubahan anggotanya dan menjalin kemampuan kerjasama antar anggota kelompoknya.

Intensitas penyuluhan berkorelasi sangat nyata dengan persepsi petani terhadap manfaat maupun pada pelaksanaan kegiatan rehabilitasi kakao. Ini menunjukkan semakin sering petani berinteraksi dengan penyuluh maka persepsi petani semakin baik. Hal ini dikarenakan adanya interaksi antara petani dengan penyuluh yang menimbulkan komunikasi di antara kedua belah pihak. Komunikasi penyuluh terhadap petani bertujuan untuk mengadakan perubahan perilaku, sehingga petani lebih terbuka untuk menerima informasi-informasi baru tentang program dan pelaksanaan kegiatan rehabilitasi pada program gernas. Sejalan dengan pendapat Kartasapoetra (1987) bahwa hubungan penyuluh yang terus menerus dengan petani akan menimbulkan rasa kekeluargaan sehingga dapat mempermudah dan memperlancar pemberian dan penerimaan informasi. Sadono (2008) juga menyimpulkan bahwa nilai penting yang dianut dalam penyuluhan adalah pemberdayaan agar terbentuk kemandirian petani Oleh karena itu dapat mengubah presepsi petani menjadi lebih baik terhadap program gernas kakao.

\section{Hubungan Karakteristik Internal dengan Partisipasi Petani pada Kegiatan Rehabilitasi Kakao}

Faktor internal yang dianalisis hubungannya dengan tingkat partisipasi petani dalam pelaksanaan rehabilitasi di Kecamatan Palolo Kabupaten Sigi, meliputi: umur, pendidikan, jumlah tanggungan keluarga, pengalaman berusahatani, luas lahan garapan, kekosmopolitan.

Tabel 5 menunjukkan bahwa faktor internal yang berhubungan dengan partisipasi petani dalam pelaksanaan rehabilitasi adalah pengalaman berusaha tani, luas lahan garapan, dan kekosmopolitan, sedangkan umur, pendidikan dan jumlah tanggungan keluarga tidak berhubungan dengan partisipasi pada pelaksanaan tahapan rehabilitasi tanaman kakao. Umur tidak berhubungan dengan partisipasi, ini 
Tabel 5. Nilai Koefisien Korelasi dan Signifikansi Hubungan Faktor Internal dengan Partisipasi Petani dalam Pelaksanaan Rehabilitasi Kakao

\begin{tabular}{lcc}
\hline \multirow{2}{*}{ Faktor Internal } & \multicolumn{2}{c}{ Partisipasi Rehabilitasi } \\
\cline { 2 - 3 } & $\mathbf{r}_{\mathbf{s}}$ & $\mathbf{P}$ \\
\hline Umur & 0,186 & 0,064 \\
Pendidikan & 0,154 & 0,125 \\
Jumlah tanggungan keluarga & $-0,069$ & 0,495 \\
Pengalaman berusahatani & $0,249^{*}$ & 0,012 \\
Luas lahan garapan & $0,253^{*}$ & 0,011 \\
Kekosmopolitan & $0,212^{*}$ & 0,034 \\
\hline
\end{tabular}

Keterangan: *) Berhubungan nyata pada $\alpha=0,05$

**) Berhubungan nyata pada $\alpha=0,01$

menunjukkan bahwa pertambahan umur seseorang tidak dapat meningkatkan partisipasinya. Umur bukan merupakan faktor yang menentukan tinggi rendahnya partisipasi seseorang. Petani yang masih muda maupun sudah tua tetap melakukan rehabilitasi kakao. Hasil penelitian ini sejalan dengan penelitian Ramadoan (2013) bahwa umur tidak berhubungan dengan partisipasi dalam kegiatan konservasi lahan, baik pada tahap perencanaan, pelaksanaan, pemanfaatan, evaluasi, maupun partisipasi secara keseluruhan.

Pendidikan juga tidak berhubungan dengan partisipasi petani dalam pelaksanaan rehabilitasi kakao. Tingkat pendidikan yang semakin meningkat tidak dapat meningkatkan partisipasi petani tersebut. Hal ini berarti pendidikan bukan merupakan faktor yang menentukan tinggi rendahnya partisipasi petani dalam pelaksanaan kegiatan rehabilitasi tanaman kakao. Berdasarkan pengamatan di lapangan dan hasil wawancara diketahui bahwa petani melaksanakan kegiatan rehabilitasi tanaman kakao, lebih mengutamakan pengalamannya dalam berusaha tani. Hasil penelitian menujukkan bahwa pengalaman berusaha tani responden sebagian besar mencapai lebih dari enam tahun. Pengalaman berusaha tani yang sudah cukup lama dapat mendorong petani lebih terampil dalam melakukan kegiatan rehabilitasi tanaman kakao.

Jumlah tanggungan keluarga negatif tidak berhubungan dengan partisipasi petani dalam pelaksanaan kegiatan rehabilitasi tanaman kakao. Hubungan ini menunjukkan bahwa semakin banyak jumlah tanggungan keluarga yang dimiliki petani menyebabkan partisipasi petani tersebut semakin menurun. Keadaan ini disebabkan oleh penambahan keluarga belum berfungsi sebagai tenaga kerja yang produktif, sehingga jumlah keluarga yang semakin banyak hanya menambah besarnya kebutuhan biaya hidup. Biaya hidup yang semakin besar dalam suatu keluarga petani berdampak pada modal pengelolaan usaha tani yang dilakukannya. Hasil penelitian ini sejalan dengan penelitian yang dilakukan oleh Erawati (2013), bahwa jumlah tanggungan keluarga yang semakin banyak mengurangi kesempatan untuk berpartisipasi dalam program.

Pengalaman berusaha tani berhubungan dengan partisipasi petani dalam pelaksanaan kegiatan rehabilitasi tanaman kakao. Petani kakao di Kecamatan Palolo Kabupaten Sigi sebagian besar telah memiliki pengalaman berusaha tani 6-38 tahun. Berdasarkan pendapat Middlebrook (1974), Tesser dan Schwarz (2003) mengatakan bahwa pengalaman seseorang pada suatu objek, secara psikologis cenderung membentuk sikap positif terhadap objek tersebut. Pandangan ini mengindikasikan bahwa petani yang memiliki sikap positif terhadap suatu program maka akan meningkatkan partisipasinya dalam pelaksanaan program tersebut.

Luas lahan garapan berhubungan dengan partisipasi petani dalam pelaksanaan kegiatan rehabilitasi tanaman kakao. Semakin luas lahan garapan maka partisipasinya dalam pelaksanaan kegiatan rehabilitasi akan semakin meningkat. Petani yang memiliki lahan garapan luas lebih memiliki kesempatan yang lebih banyak untuk memanfaatkan lahannya untuk pengembangan usaha tani kakao. Besarnya luas lahan garapan akan memberikan keuntungan yang lebih besar, sehingga meningkatkan semangat petani untuk melaksanakan kegiatan rehabilitasi. Sejalan dengan penelitian hasil Puspasari (2010) bahwa luas lahan garapan berhubungan nyata dengan partisipasi dalam mengevaluasi kegiatan pengembangan tanaman karet unggul.

Variabel kekosmopolitan berhubungan 
Tabel 6. Nilai Koefisien Korelasi dan Signifikansi Hubungan Faktor Eksternal dengan Partisipasi Petani dalam Pelaksanaan Rehabilitasi Kakao

\begin{tabular}{lcc}
\hline \multirow{2}{*}{ Faktor Eksternal } & \multicolumn{2}{c}{ Partisipasi Rehabilitasi } \\
\cline { 2 - 3 } & $\mathbf{r}_{\text {s }}$ & $\mathbf{p}$ \\
\hline Dukungan pasar & $-0,035$ & 0,727 \\
Ketersediaan tenaga kerja & $-0,003$ & 0,980 \\
Ketersediaan informasi & 0,026 & 0,800 \\
Dukungan kelompok tani & $-0,128$ & 0,205 \\
Intensitas penyuluhan & $-0,002$ & 0,987 \\
\hline
\end{tabular}

nyata dengan partisipasi petani dalam pelaksanan kegiatan rehabilitasi tanaman kakao. Hubungan ini menunjukkan bahwa semakin tinggi tingkat kekosmopolitan maka partisipasinya akan semakin meningkat. Kekosmopolitan yang dimiliki petani berdampak positif terhadap partisipasi dalam kegiatan rehabilitasi, seperti dalam kegiatan pemeliharaan, sanitasi, pemupukan, dan pengendalian hama. Petani yang banyak menerima informasi tentang rehabilitasi salah satunya sambung samping akan mampu melakukan hal tersebut dengan baik. Hasil penelitian ini sejalan dengan penelitian yang dilakukan Manoppo (2009) bahwa kekosmopolitan berhubungan positif dengan partisipasi wanita tani dalam usaha tani kakao.

\section{Hubungan Faktor Eksternal dengan Partisipasi Petani pada Kegiatan Rehabilitasi Tanaman Kakao}

Faktor eksternal yang dianalisis hubungannya dengan partsipasi petani pada pelaksanaan rehabilitasi mencakup dukungan pasar, ketersediaan tenaga kerja, ketersediaan informasi, dukungan kelompok tani, dan intensitas penyuluhan (Tabel 6). Tabel 6 menunjukkan bahwa sebagian besar faktor eksternal negatif tidak berhubungan dengan partisipasi. Dukungan pasar negatif tidak berhubungan nyata terhadap partisipasi pada pelaksanaan rehabilitasi. Hubungan ini menggambarkan semakin tinggi dukungan pasar tidak dapat meningkatkan partisipasi petani dalam pelaksanaan rehabilitasi. Berdasarkan pengamatan di lapangan hal ini disebabkan petani lebih banyak menjual produksinya kepada pedagang pengumpul yang berada di lingkungan petani. Alasan petani melakukan penjualan hasil produksi kepada pedagang pengumpul bertujuan agar lebih cepat memperoleh uang hasil penjualan. Pedagang pengumpul yang ada di lokasi penelitian biasanya membeli hasil produksi, langsung mendatangi petani. Hal ini mempermudah akses petani untuk melakukan penjualan secara cepat, dibandingkan dengan petani harus menjual ke pedagang besar yang relatif lebih sulit dan lama.

Ketersediaan tenaga kerja negatif berhubungan tidak nyata dengan partisipasi pada pelaksanaan rehabilitasi tanaman kakao. Meningkatnya ketersediaan tenaga kerja tidak dapat meningkatkan partisipasi petani tersebut. Petani kakao di Kecamatan Palolo tidak tergantung pada ketersediaan tenaga kerja yang berasal dari luar, melainkan lebih menggunakan tenaga kerja dalam keluarga. Alasan petani jarang menggunakan tenaga kerja dari luar disebabkan karena sebagian besar lahan yang digarap berskala sempit hanya berkisar satu Ha. Kondisi lahan yang sempit tidak memungkinkan petani untuk mengupah tenaga kerja luar, karena penghasilan yang diperoleh dari usahatani kakao masih rendah.

Ketersediaan informasi tidak berhubungan dengan partisipasi petani pada pelaksanaan rehabilitasi tanaman kakao. Tingkat ketersediaan informasi yang semakin meningkat tidak dapat meningkatkan partisipasi petani tersebut. Hal ini menggambarkan bahwa ketersediaan informasi bukan merupakan faktor yang menentukan tinggi rendahnya partisipasi petani. Berdasarkan pendapat petani ketersediaan informasi mengenai program gernas kakao sulit diakses oleh petani. Informasi tersebut tersedia di Kantor Balai Penyuluhan, di Dinas Pertanian, sehingga bagi petani butuh waktu untuk mengunjungi tempat tersedianya informasi tersebut.

Dukungan kelompok tani negatif tidak berhubungan dengan partisipasi rehabilitasi tanaman kakao. Hubungan ini menggambarkan semakin tinggi dukungan kelompok tani tidak dapat meningkatkan partisipasi petani dalam pelaksanaan kegiatan rehabilitasi kakao. Hal ini menunjukkan bahwa kelompok tani yang ada belum dapat mendukung 
petani dalam partisipasi tahap rehabilitasi tanaman kakao. Berdasarkan wawancara di lapangan disebabkan karena adanya ketidakpercayaan antara anggota kelompok dengan pengurus kelompok tani. Kelompok tani yang seharusnya dapat berperan sebagai wahana belajar bagi petani tidak sesuai dengan tujuan kelompok yang diharapkan. Abbas (1995) mengemukakan bahwa peranan kelompok tani adalah sebagai wahana belajar bagi petani agar terjadi interaksi, guna meningkatkan pengetahuan, sikap dan keterampilan dalam berusahatani yang lebih baik serta berperilaku lebih mandiri untuk mencapai kehidupan yang lebih sejahtera.

Intensitas penyuluhan negatif tidak berhubungan dengan partisipasi petani dalam tahap rehabilitasi usaha tani kakao. Hubungan ini menggambarkan semakin tinggi intensitas penyuluhan tidak dapat meningkatkan partisipasi petani dalam pelaksanaan kegiatan rehabilitasi kakao. Berdasarkan pengamatan dan hasil wawancara menyimpulkan bahwa informasi yang diperoleh dari kegiatan penyuluhan yang dilakukan di lokasi penelitian tidak sesuai dengan kondisi di lahan kakao petani sendiri. Rogers (2003) mengemukakan bahwa keberhasilan kerja agen perubahan tergantung pada: 1) besarnya usaha yang dilakukan penyuluh dalam berkomunikasi dengan petani, 2) kredibilitas penyuluh di mata petani, misal: kedekatan emosi dan keberpihakan terhadap petani serta mau menerima umpan balik, dan 3) tingkat pemahaman penyuluh terhadap kebutuhan petani.

\section{Kesimpulan}

Persepsi petani terhadap manfaat maupun pelaksanaan kegiatan rehabilitasi kakao sebagian besar sudah cukup. Adanya kegiatan rehabilitasi tanaman kakao, bagi petani bermanfaat. Tingkat partisipasi petani dalam pelaksanaan kegiatan rehabilitasi tanaman kakao juga sebagian besar cukup. Petani terlibat dalam kegiatan-kegiatan rehabilitasi tanaman kakao yang meliputi sambung samping, perawatan dan pengendalian hama dan penyakit. Karakteristik internal yang berhubungan dengan persepsi petani terhadap manfaat kegiatan rehabilitasi pada program gernas hanya variabel kosmopolitan, sementara yang berhubungan dengan persepsi petani terhadap pelaksanaan kegiatan rehabilitasi pada program gernas adalah luas lahan garapan dan kosmopolitan.

Faktor eksternal yang berhubungan dengan persepsi petani terhadap manfaat kegiatan rehabilitasi pada program terdiri dari dukungan pasar, ketersediaan tenaga kerja, ketersediaan informasi serta intensitas penyuluhan, sementara pada tingkat pelaksanaan hanya dukungan kelompok tani dan intensitas penyuluhan. Karakteristik internal yang berhubungan dengan partisipasi petani dalam pelaksanaan rehabilitasi tanaman kakao terdiri dari pengalaman usaha tani, luas lahan garapan dan kosmopolitan. Faktor eksternal tidak ada yang berhubungan dengan partisipasi petani.

Berdasarkanhal tersebutmaka dapat disarankan upaya meningkatkan persepsi dan partisipasi petani kakao dalam pelaksanaan rehabilitasi dapat dilakukan melalui peningkatan kosmopolitan, luas lahan garapan, dukungan pasar, ketersediaan informasi serta meningkatkan intensitas penyuluhan. Pemerintah baik pusat maupun daerah perlu memperhatikan sasaran program gernas yang diberikan kepada petani sehingga program tersebut tepat sasaran dan dirasakan langsung manfaatnya oleh petani.

\section{Daftar Pustaka}

Abbas S. 1995. 90 Tahun Penyuluhan Pertanian di Indonesia. Jakarta (ID): Deptan.

Berlo DK. 1960. The Process of Communication: An Introduction to Theory and Practice. New York (US): Holt Rinehart and Winston Inc.

Erawati I, Massadun. 2013. Partisipasi Masyarakat dalam Pengelolaan Sumber Daya Lingkungan Mangrove di Desa Bedono Kecamatan Sayung. Jurnal Ruang (Jurnal Perencanaan Wilayah dan Kota). 1(1): 31-40.

Herawati, Pulungan I. 2006. Faktor-Faktor yang Berhubungan dengan Partisipasi Kontaktani dalam Perencanaan Program Penyuluhan Pertanian. Jurnal Penyuluhan 2 (2): 107-114.

Ifa A. 2007. Persepsi Petani Terhadap Inovasi untuk Menggunakan Pupuk Kompos Kotoran Ternak Produk P4S Bumi Lestari Sragen: kasus petani di Desa Gondang Kecamatan Gondang Kabupaten Sragen.

Kartasapoetra AG. 1987. Teknologi Penyuluhan Pertanian. Jakarta (ID): PT. Bina Aksara.

Kartono. 2009. Persepsi Petani dan Penerapan Inovasi Pengelolaan Tanaman dan Sumber Daya Terpadu Padi Sawah di Lokasi Prima Tani Kabupaten Serang Provinsi Banten. [Tesis] Bogor (ID): Institut Pertanian Bogor.

[KEMENTAN] Kementerian Pertanian. 2012. Peningkatan Produksi, Produktivitas dan Mutu Tanaman Rempah dan Penyegar. Pedoman Teknis Gerakan Nasional Peningkatan Produksi Dan 
Mutu Kakao. Jakarta (ID).

Kumba FF. 2003. Farmer Participation In Agricultural Research And Extension service in Namibia. Journal Intagric Extension Edu. 10(3): 47-55.

Manoppo CN. 2009. Faktor-faktor yang Berhubungan dengan Partisipasi Wanita Tani dalam Usahatani Kakao. Kasus di Kecamatan Palolo Kabupaten Donggala Provinsi Sulawesi Tengah. [Tesis] Bogor (ID): Institut Pertanian Bogor.

Middlebrook. 1974. Social Psyhology and Modern Life. New York (US): Alfred Knopf Inc.

Puspasari S. 2010. Persepsi dan Partisipasi Peladang Berpindah dalam Kegiatan Pengembangan Tanaman Kehidupan Model HTI Terpadu di Kalimantan Barat [Tesis] Bogor (ID): Institut Pertanian Bogor.

Ramadoan S. 2013 Peran PKSM dalam Meningkatkan Fungsi Kelompok Tani dan Partisipasi Masyarakat di Kabupaten Bima NTB. Jurnal Penelitian Sosial dan Ekonomi Kehutanan. 10(3): 199-210.

Rukka H, Buhaerah, Kadir S. 2008. Peran Kelompok
Tani dalam Pemenuhan Kebutuhan Usaha Tani. Kasus Petani Padi Sawah di Kelurahan Tamarunang, Kecamatan Somba Opu, Kabupaten Gowa. Jurnal Agristem. 4 (2): 77-86

Rogers EM. 2003. Diffusion of Innovations. New York (US): The Free Press.

Sadono D. 2008. Pemberdayaan Petani: Paradigma Baru Penyuluhan Pertanian di Indonesia. Jurnal Penyuluhan 4(1): 65-74.

Sinartani.2014.PemberdayaanPetaniKakao.[Internet]. [dapat diunduh dari http://tabloidsinartani.com].

Susiatik T. 1998. Persepsi dan Partisipasi Masyarakat terhadap Kegiatan membangun Masyarakat Desa Hutan Terpadu (PMDHT) di Desa Mojorebo Kecamatan Wirosari Kabupaten Dati II Grobogan Jawa Tengah. [Tesis] Bogor (ID): Institut Pertanian Bogor.

Tesser A, Schwarz N. 2003. Blackwell Handbook of Social Psychology: Intraindividual Prosesses. Malden: Blackwell Publishers. 